\title{
Strategic Decisions Needed Now
}

The German Physical Society, on the occasion of the first follow-up conference of the signatories of the Rio convention on the climate (Berlin, 28 March - 7 April 1995), issued a Memorandum on Energy appealing for public support for energy policies. As a major technical and economic power, Germany should take a lead in implementing measures to stabilise the Earth's climate. The Memorandum, summarised below, recommends that Germany reduce its $\mathrm{CO}_{2}$ emissions to $20 \%$ of today's level by the year 2050. It notes that despite several positive high-level declarations, long-term planning is still lacking and that guidelines are needed to strengthen the ways that will be applied well into the next century to guarantee protection of the climate.

The uncontrolled emission of green-house gases, especially carbon dioxide, enhances in a very dramatic way our atmosphere's natural green-house effect. The atmosphere's normal $\mathrm{CO}_{2}$ content gives rise to an average global temperature of the atmosphere of $15^{\circ} \mathrm{C}$ that permits life as we know it to develop. The rapidly growing and enormous use of fossil fuels accumulated over millions of years will lead to a doubling of the atmosphere's $\mathrm{CO}_{2}$ content in the next century (an effect that is accelerated by other gases such as ozone and nitrous oxide). Calculations [1] by the Intergovernmental Panel on Climate Change (IPCC) working under the auspices of the World Meteorological Organization show that this doubling will lead to an increase of 1.5 to $4.5^{\circ} \mathrm{C}$ in the average global temperature. The latest data demonstrate that the atmosphere has already warmed up by more than $0.5^{\circ} \mathrm{C}$, and an increase of $2.5^{\circ} \mathrm{C}$ corresponds to one-half of the difference in temperatures between recent ice ages and the intervening warm periods. A $0.5 \mathrm{~m}$ increase in the mean sea level, must be expected along with the disappearance of major wheat growing regions, enlargement of sub-tropical dry zones, deforestation in the temperate zones, and a dangerous

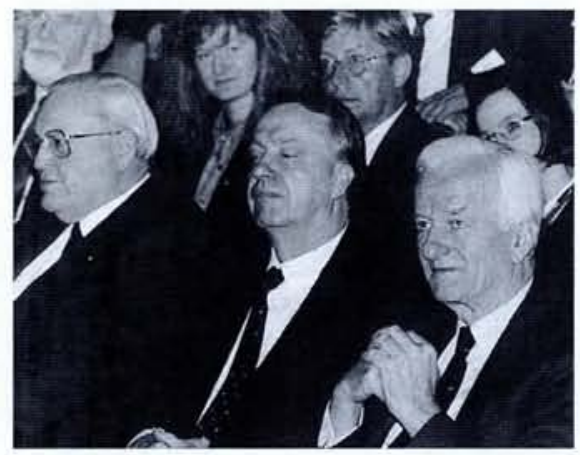

From the left, R. Herzog, the President of Germany, with J. Rüttgers, the Minister for Education, Science, Research, and Technology, and R. von Weizsäcker, the former President, at the cermony to mark to 150th anniversary of the Germany Physical Society on 22 March. The cermony formed part of the Society's 59. Physikertagung which included a press conference announcing the 1995 Memorandum on Energy. melting of the tundra's permafrost. The paradox is that the people who will suffer most from these climatic changes are not responsible for their development.

The Rio de Janerio convention of 1992 agreed that the joint efforts of nations should aim to limit over the next 100 years the increase in the atmosphere's temperature to $1^{\circ} \mathrm{C}$. To reach this goal, the IPCC has recommended a $40 \%$ reduction by 2050 of $\mathrm{CO}_{2}$ emissions. The highly industrialised countries are responsible for three-quarters of today's $\mathrm{CO}_{2}$ emissions so they will have cut back to a more than proportional $20 \%$ of their present-day levels to achieve the proposed limit. Action is unavoidable since even with this target, the expected increases of the world's population and its economic activity imply a doubling of the atmosphere's $\mathrm{CO}_{2}$ content within about 100 years.

The German Physical Society is aware that there has not been enough public discussion about the issues involved. One may also forget that the reductions cannot be achieved through separate, independent steps without an overall strategy. Moreover, planning must be implemented now because several decades will pass before effective technical solutions are fully exploited in buildings, transport, heating, housing, and power generation, essentially owing to the extended lifespans of existing systems. One should also be aware that reasonable effort in all of these areas will not be sufficient to meet the proposed limit.

The recommendations (see insert) of the Society's 1995 Memorandum on Energy [3], in endorsing a parliamentary committee's [2] recommendations for energy saving and a coordinated world-wide energy policy, stress the need for long-term planning. Economic incentives to encourage industry to adopt energy-saving measures are also required since improved technology for all of the main areas (renewable; nuclear; energy efficient) will not be commercially viable in the short term. Job creation in new industries is expected to offset job loss, a sensitive political issue. The Memorandum then discussed in more detail technical measures for each of the three main energy consuming sectors, namely heat generation (accounting for $40 \%$ of the Germany's energy consumption), transport (20\%) and electricity generation $(40 \%)$.

\section{The Recommendations}

- Man's consumption of energy must be related not to the resources available but rather to its effect on the world's climate. Supply based on fossil fuels must be reduced quickly and drastically to avoid problems related to $\mathrm{CO}_{2}$ emissions and associated climatic changes.

- The lifespans of buildings and energysupply systems are so long that an effective reduction in $\mathrm{CO}_{2}$ emissions within the first half of the next century depends on decisions taken today.

- The industrialised countries must reduce $\mathrm{CO}_{2}$ emissions to $20 \%$ of today's level by the year 2050. Considerable investment will be needed to achieve this difficult goal, so political decisions providing long-term guidelines and the necessary economic incentives must be taken quickly.

\section{Memorandum on Energy}

The German Physical Society's 1995 Memorandum on Energy [3] follows on from a statement issued in 1987 jointly with the German Meteorological Society, the recommendations of a parliamentary committee [2] and the work [1] carried out by the Intergovernmental Panel on Climate Change (IPCC). It also falls within the framework of the follow-up to the 1992 Rio de Janerio convention on the climate.

[1] Intergovernmental Panel on Climate Change (IPCC): Climate Change 1992, Supplementary Report to the IPCC Scientific Assessment prepared by IPCC Working Group No. 1; Ed.: J.Z. Houghton et al. (Cambridge University Press; 1993); Radiative Forcing on Climate Change, Report of the IPCC Scientific Assessment Working Group - Summary for Policy Makers (WMO \& UNEP, Geneva; 1994).

[2] Enquete-Kommission "Schutz der Erdatmosphäre" des Deutschen Bundestages: Mehr Zukunft für die Erde - Nachhaltige Klimapolitik für daverhaften Klimaschutz (Economica Verlag, Bonn, 1995); Klimaänderung gefährdet globale Entwicklung (Economica-Verlag, Bonn; 1992).

[3] Zukünftige klimaverträgliche Energienutzung und politischer Handlungsbedarf zur Markteinführung neuer emissionsmindernder Techniken (Future climate-friendly energy use and the political initiatives needed to commercialise new emissions-reducting technology), Energiememorandum 1995 der Deutschen Physikalischen Gesellschaft, Physikalische Blätter 51 (1995) 388 .

\section{ECONOMY - ENERGY - ENTROPY Europhysics Study Conference CERN, Geneva; 10-13 May 1996}

Organized by the EPS Action Committee for Physics and Society - By invitation only

Conference chair, contact for information \& applications for participation to:

E.W.A. Lingeman, NIKHEF, POB 94395, NL1090 GJ Amsterdam. Tel.: +31-20-592 21 17; Fax: +31-20-592 2165; E-mail: ed@nikhef.nl

FURTHER INFORMATION

On EurophysNet at http://128.178.177.16 